\title{
THE ROLE OF HALAL CERTIFICATION ON PURCHASE INTENTION TOWARDS FOOD PRODUCTS FROM MENA COUNTRIES: A SEM STUDY
}

\author{
Firdaus Fanny Putera Perdana ${ }^{1}$, Muhammad Tahir Jan², Remzi Altunişik ${ }^{3}$, \\ Irwandi Jaswir ${ }^{4}$ and Betania Kartika ${ }^{5}$ \\ ${ }^{1}$ International Islamic University Malaysia, Gombak, Selangor, Malaysia, \\ firdausfannyputeraperdana@gmail.com \\ ${ }^{2}$ International Islamic University Malaysia, Gombak, Selangor, Malaysia, tahirjan@iium.edu.my \\ ${ }^{3}$ Sakarya University, Faculty of Business, Dept. of Business Administration, Sakarya, Turkey, \\ altunr@sakarya.edu.tr \\ ${ }^{4}$ International Islamic University Malaysia, Gombak, Selangor, Malaysia, irwandi@iium.edu.my \\ ${ }^{5}$ International Islamic University Malaysia, Gombak, Selangor, Malaysia, betania@iium.edu.my
}

\begin{abstract}
Kullu Halal (all Halal) is a concept that is highly applied in the Middle Eastern and North African (MENA) region as the majority of the population is Muslim. Many products from non-Muslim countries are also exported to the MENA countries and some of them are exposed to animal-based ingredients. Halal certification studies in the MENA region are found to be quite minimal to non-existent. The paper is designated to analyze the effects of Halal certification towards the purchase intention of Muslim consumers on food products from Muslim majority countries in the MENA countries. Theory of Planned Behavior (TPB) was used as a platform to predict the consumers' intention to purchase the Halal certified products. A self-administered questionnaire was selected as a method and the respondents are the Muslim consumers living in certain areas of Klang Valley, Malaysia. Five hundred questionnaires were distributed, and 417 questionnaires were considered usable. Structural Equation Modeling (SEM) was used as a method in this research. Attitude, Subjective Norm, and Perceived Behavioral Control showed a strong correlation with Purchase Intention and the results were statistically significant at $p<0.05$. Algeria was found to be the least trustworthy country by the respondents, followed by Iran, Lebanon, Iraq, and Bahrain. The results indicate that the presence of Halal certification is important and will be profitable for the food industry players in the MENA region. Despite being Muslim majority countries, it is important to ensure the presence of Halal certification in the products from MENA countries, especially from those that received low scores in the country of origin study.
\end{abstract}

Keywords: Halal Certification, Islamic Marketing, Muslim Consumers, Consumer Behavior, Middle East, North Africa, Food Products.

JEL Classification: G18; G21; G28.

Article history:

Received : November 11, 2018

Revised : March 01, 2019

Accepted : March 04, 2019

Available online : March 15, 2019

https://doi.org/10.21098/jimf.v5i1.1048 


\section{INTRODUCTION}

\subsection{Research Background}

The Halal food industry is one of the most profitable industries as in 2015, valued at \$1.17 trillion with the revenues estimated to reach $\$ 415$ billion (Reuters, 2015). Apart from being highly profitable, the Halal food industry is also considered as a form of lifestyle choice and quality assurance. Nowadays, the presence of the Halal industry is no longer only associated with religiosity (Lada, Tanakinjal, \& Amin, 2010). However, it is important to note that some parts of the word do not have the privilege to find Halal food easily. People who live in non-Muslim countries will surely have difficulties to get Halal certified food products on daily basis as the regulations and the systems are controlled by the non-Muslim players. Halalcertified food products are also very minimal to non-existent in MENA countries as most countries apply the concept of Kullu Halal (all halal), assuming all the products are Halal unless stated otherwise (Cochrane, 2016). Halal label and Halal certification are not mandatory in the MENA region (Neiburg, 2013).

However, in the late 1970s, many Muslim majority countries in MENA started to heavily import the food products and some ingredients from European, American, Asian countries. Some of those products are animal-based and therefore the Halal integrity of the products is something that can be considered doubtful (Latif, Mohamed, Sharifuddin, \& Mahir, 2016). Tieman (2015) stated that food production and trade are some of the aspects considered as weak in the Halal value chain. The statement is supported by a research conducted by Ireland and Rajabszadeh (2011) as the results indicated that 86.5 percent of respondents from supermarkets across UAE were having great concern of the Halal status of at least one food category.

Many food products imported from Muslim majority countries in MENA are available in supermarkets across Malaysia, especially in the Arab or Middle Eastern populated areas. Although Halal certification comes from Muslim majority countries, the certification is not present in the products as these countries have a strong confidence in the Halal integrity of their products. An investigation towards some Arab shops in Klang Area, Malaysia was performed, and it was found that some products with the Arabic writings (MENA countries are the countries of origin) were produced in the countries like Netherlands, Spain, Thailand, Vietnam, China, and India. These countries are not Muslim majority countries, and knowing the food trade and production are considered weak in the Halal value chain, cross-contamination may easily occur during the process, whether it is production process or transportation process.

Many previous studies discussing the importance of Halal certification focusing on general food products. Studies regarding the importance of Halal certification towards food products from certain countries (country of origin study), particularly the ones produced by food producers in MENA region, have been known to be very limited to non-existent. Empirical studies regarding the food products from MENA region are also rarely available. An extensive literature review regarding violation cases in MENA region is later presented to support the idea that it is important to do this type of study. The findings led the researchers to further study regarding the importance of the Halal certification towards the food products from Muslim majority countries in MENA. The study proposes 
an empirical research that will further analyze the purchase intention of Muslim consumers in Malaysia and the Theory of Planned Behavior (TPB) was utilized as a platform to predict consumer behavior. Apart from that, a country of origin study towards the Muslim majority countries in MENA was also conducted to understand better about the consumers' level of trust towards the products from Muslim majority countries in MENA when Halal certification is not present. The results are intended to provide guidelines for the food industry players in Muslim majority countries in MENA. Non-Muslim countries have been known to be very strong players in the Halal food industry and even they also take a high interest in developing Halal markets in general (Heidarzadeh \& Ramezani, 2011).

\subsection{Halal Certification Benefits}

The issuance of the Halal certification has proved to be a lucrative decision to many companies as the presence of the Halal certification allows them to increase the sales and acquire more profits. Fast food chains like Taco Bell, McDonald's, Burger King, and KFC experienced around 20\% increase of the new consumers after the issuance of the Halal certification at some of their premises (Sabri, 2006). A frozen food company in Malaysia improved its target markets by $100 \%$ upon the presence of Halal certification in its products. Many European companies also were able to further strengthen their positions in Asian markets due to the attachment of Halal certification in their products (Liow, 2012).

Non-Muslim Majority countries have proved to show a huge interest in developing Halal markets and they have been raking such a huge profit from the presence of Halal certification. Eighty percent of the Halal food markets are fully controlled by the non-Muslim countries (Power, 2008). Around 25\% of the financial institutions in Malaysia are controlled by the non-Muslim owners (Wilson \& Liu, 2010). In term of meat export, Brazil is surely one of the most successful countries as the country exports more than 6.5 billion worth of Halal meat around the world. Apart from Brazil, countries like Singapore, South Africa, New Zealand, and Australia are also known to be strong players in the Halal industry (Riaz \& Chaudry, 2004). McDonald's restaurants in Singapore also showcased a huge success upon the issuance of the Halal certification as they were able to entice around eight million customers within a short period of one year (Lada et al., 2010). Singapore also achieved a major success in their food exports to the United Arab Emirates (UAE) by as it increased by $67 \%$ since the Islamic Religious Council of Singapore (MUIS) was recognized by the UAE, as reported by International Enterprise Singapore website. Nestle is a food giant from Switzerland that shows a continual interest in expanding and developing its Halal food divisions. Their Halal versions have also been available even in countries like France, Germany, and the UK since 2004. Almost 20\% (85 of 456) Nestle factories around the world are Halal certified.

It is highly crucial that Muslim majority countries in MENA participate in the development of Halal food industry and eventually become the king of their own kingdom. If the Muslim majority countries start to be the important players in the industry, the results will greatly impact the development of the Ummah. Improving the quality of Islamic education and the daily lifestyle of Muslim consumers can 
be achieved when the countries start to make profits from this valuable business opportunity. Once the success is achieved, Muslim majority countries and Islamic countries in MENA will be more empowered nations in the future.

\subsection{Research Objectives}

The objective of the research is to uncover the role of Halal certification in purchase intention of Muslim consumers in Malaysia towards purchasing food products from Muslim majority countries in MENA. Theory of Planned Behavior (TPB) was used as a base theory to answer some research questions. The results of this research are intended to be a guide to the food industry players in the MENA region, especially the Muslim majority countries and Islamic countries. The results allow them to prioritize and strategize their marketing concepts to ensure that their products are well accepted. The study is also designed to increase the awareness towards the importance of the Halal certification, to both the food industry players and consumers. The higher their awareness, the more products will be Halal certified. The presence of the Halal certification is a form of protection to the Muslim consumers, and it prevents them from consuming non-Halal products. As far as the food industry players are concerned, it is hoped that the presence of the Halal certification in their products will help increase the sales and catapult the profitability. As Halal certification is an important process, the products are also expected to be better known internationally. As they have more power to be internationally recognized, it is also possible for them to compete with the food industry giants like Nestle and Cadbury that have strongly implemented the Halal certification in the past few years. The country of origin study was investigated to discover the level of the consumers' trust and the results are expected to encourage them to be more active in the Halal certification development. In conclusion, the research objectives are as follows:

1. To analyze the impact of Attitude on Intention to Purchase

2. To investigate the impact of Subjective Norm on Intention to Purchase

3. To evaluate the impact of Perceived Behavioral Control on Intention to Purchase

4. To understand the Muslim consumers' level of trust towards the products from the Muslim majority countries in MENA

\section{LITERATURE REVIEW}

\subsection{Cases in the Middle Eastern and North African Region}

It is important that Halal food products are produced in the sense that Islamic rules (Sharia Law) are followed and it is crucial that the supply chain integrity is very well maintained. All the processes namely; food preparation, handling, packaging must also be Halal (Yildırım, 2011). Statement of "no pork" nor "no alcohol" in the food package does not necessarily make the product Halal (Karaman, 2012). There are so many complicated processes in the food industry nowadays and unfamiliar ingredients may be unknowingly present in the daily food products. Many ingredients are imported, and they do not provide some paperwork that 
ensures the Halal integrity of the products. Some of them are even animal-based products and therefore it is hard to predict the Halal status of these ingredients. (Batu \& Regenstein, 2014).

Turkey is a country that serves so many non-Muslim tourists, and some restaurants and hotels have pork in their menu. However, there is no guarantee that there is a segregation between the utensils used for Haram food and the ones used for Halal food. A 5-star restaurant in Turkey once was fined as it was found to serve pork and offer Iftar at the same time. The cross-contamination between pork and Halal meats is not allowed by the Turkish government (Yayımlandığ Resmi Gazete, 2009). However, pork-based additives were also suspected to be used in some food production processes (Batu, 2012). The alcohol consumption and production in Turkey have shown an increase these past few years, and it is also suspected that there may be some alcoholic ingredients in the food products (Akgündüz, 2012). Bingöl city (located in the East of Turkey) was reported to have difficulties in dealing with the Halal integrity as there were some dirty bread factories, some products containing Halal animal not slaughtered according to Sharia Law, as well as some products containing pig-based additives (Aslan, 2016).

Iran was extremely well known for its ability to produce fine wine back then before the Islamic revolution. It was argued restaurants in Iran provide pork and wine in their menu. These types of restaurants are not open for public and they operate secretly to ensure that only their customers are informed about their presence (Alijani, 2015). Doosti, Ghasemi, and Rahimi (2014) conducted a study that investigated some meat products in Iran and the findings showed that Haram substances were present in more than $5 \%$ of the studied products. Despite having more than 50\% Muslims (27\% Sunni and 27\% Shia) in the country, Lebanon is more importantly a country of diversity. In addition, despite there are so many religions and practices applied, Kullu Halal concept is also highly believed in Lebanon. Even they also believe all meat products are Halal unless stated otherwise. The big slaughterhouses usually slaughter only Halal animals and Sharia Law is applied in the slaughtering process. However, it is not necessarily the case for the smaller slaughterhouses as they may have more than just beef, lamb and chicken. People in a certain region of Lebanon are also known to consume pork on daily basis and therefore, there is a chance of cross-contamination and this is such a big issue for the Muslim consumers (Cochrane, 2016).

It was claimed by Mufti Abdullah Nana (2013) that $90 \%$ of meat in Saudi Arabia was considered not Halal as he discovered that some chickens are slaughtered using a machine, some meats are not slaughtered by the Muslims, as well as doubtful meats were imported to Saudi Arabia. Ninety percent of fast food industries in Saudi Arabia (McDonald's, KFC, and many more), including Al-Baik, rely heavily on imported ingredients. Some of those come from the non-Muslim countries like the Netherlands, Brazil, France, and other countries whose Halal certification processes are highly questionable. Sheikh Back then in 2010, a famous ulema from Algeria, Shamseddin Bouroubi issued a fatwa regarding consumption towards Indian meat. It was prohibited as he believed that the animals were most likely not slaughtered according to Sharia Law (Belamri, 2010). Jalel Aossey (2009), the director of Midamar, a US-based international food supplier, and foodservice 
equipment, claimed that the Halal status of around ninety-five percent of American food items available in supermarket shelves in Middle Eastern countries is highly questionable.

\subsection{Purchase Intention}

Purchase Intention has become one of the most interesting topics for the researchers, as it is a platform that can improve marketing strategy. Ajzen and Fisbein (1975) defined behavioral intention as "... a person's location on a subjective probability dimension involving a relation between himself and some action that he will perform some behavior". Shortly, as applied in the TPB, the direct antecedent of a certain behavior is the "intention" to perform the questioned behavior. TPB assumes that the intention is dictated by three kinds of considerations or beliefs: attitude, subjective norm and perceived behavioral control (Ajzen 2015). Purchase Intention plays a huge role in answering the Halal Certification related studies as it is imperative to learn the perspective of the consumers. Many researchers have explored Halal products purchase intention and different theories were applied to ensure that their research questions were answered accordingly.

Lada et al. (2010) conducted a study that applies the theory of reasoned action (TRA) as the basic theory and it investigated the effects of attitude and subjective norm. It was discovered that both subjective norm and attitude are strongly correlated to the intention to choose Halal products. Purchase intention towards Halal products has become one of the issues that garners the interest of the Halal marketing researchers. Aziz, Nyen, and Chok (2013) conducted a study that reviewed the effects of the determinant factors (Halal Awareness, Halal Certification, Product Quality, Marketing Promotion, and Brand) on the Purchase Intention. All mentioned determinant factors, except for product quality, were found to have a positive relationship with the purchase intention. Jaafar, Lalp, and Naba (2013) performed a research that investigated some determinants that include Intrinsic (Perceived Quality, Perceived Risk, Perceived Value), Extrinsic (Perceived Price, Advertisement, Packaging, Store Image), Consumers' Attitude (Trust, Familiarity, Perceived Economic Situation). The objects of the study were private labeled Halal products. The study indicated that all the determinant factors showed a positive relationship with purchase intention.

\subsection{The Theory of Planned Behavior}

Theory of Planned Behavior is one of the most popular theories applied in marketing and behavioral (psychology) studies and this theory was initially popularized by Ajzen (1991). Many researchers employed the TPB as a basic theory for their food-related studies (Al-Swidi, Huque, Hafeez, \& Shariff, 2014; Arvola et al., 2008; Tarkiainen \& Sundqvist, 2005) and some also utilized TPB to help answer their Halal related research questions (Bonne \& Verbeke, 2008; Khalek \& Ismail, 2015). The TPB is also deemed very popular by the Halal purchase intention researchers (Abd-Rahman et al., 2015; Mukhtar \& Butt, 2012; Salehudin \& Luthfi, 2011a; Tifaoui, 2011). 
TPB is also one of the most commonly used theories in the Halal products purchase intention studies. Afendi et al. (2014), and Khalek and Ismail (2015) benefited TPB as a theory to uncover their research questions. Afendi et al. (2014) conducted a research towards the Muslim consumers in Perlis, and the results showed that all the factors (attitude, subjective norm, and perceived behavioral control) were found to positively affect the purchase intention. Supporting the results of the previously mentioned study, Khalek and Ismail (2015) utilized TPB to learn the behavior of the Gen Y in Malaysia and the results indicated that all the three factors also have a positive relationship with the purchase intention.

\subsubsection{Attitude}

An attitude of a certain individual is determined by their perception about the possible consequences/outcomes of conducting such behavior and the evaluation of those consequences (Ajzen \& Fishbein, 1980). Many scholars also claimed that attitude plays a huge role in impacting the consumers' intention to purchase Halal products. Afsari, Suryantini, \& Mulyo (2017) conducted a consumer behavior study towards the Halal-certified snacks in Yogyakarta and attitude was found to have a strong relationship with the intention to purchase. Suki and Salleh (2016) also indicated that attitude has a very important role in predicting the consumer's intention to patronize Halal stores. In line with the research by Suki and Salleh (2016), Afendi et al. (2014) also showed that attitude was a determining factor in the purchase intention towards Halal products in Perlis, Kedah. Mukhtar and Butt (2012) also indicated an agreement in their findings as they also found attitude to be an important factor that has a strong impact on the intention to choose Halal products. Abd-Rahman et al. (2015) also showed in their findings that attitude is a factor that has a strong effect on the purchase intention. Based on the studies, it is decided to propose a hypothesis $\mathrm{H} 1$ as follows:

H1: Attitude positively affects Purchase Intention

\subsubsection{Subjective Norm}

Subjective norm is hugely linked to the pressure of social normative presence. A person's decision to conduct a certain behavior may as well be influenced by their family members, friends, colleagues, teachers, and communities. Many researchers showcased the importance of the subjective norm as a great factor to predict the consumers' intention to purchase a product (Dean, Raats, \& Shepherd, 2008; Eves \& Cheng, 2007; Govind \& Pathak, 2016; Othman \& Rahman, 2014; Vermeir \& Verbeke, 2008). It is also known that subjective norm is a factor that affects the purchase intention towards the Halal products. Abd-Rahman et al. (2015) performed a research that analyzed the purchase intention towards the Halal cosmetics and the results indicated that the subjective norm was a strong factor that influences the purchase intention. Supporting the research by Abd-Rahman et al. (2015), Afendi et. al (2014) also indicated in their study that subjective norm has a positive relationship on purchase intention towards the Halal products in Perlis, Malaysia. Alam and Sayuti (2011) also claimed that the subjective norm 
has a strong impact in influencing consumers' intention to purchase Halal food. Haro (2016) and Mukhtar and Butt (2012) also indicated that subjective norm has a positive relationship with the purchase intention of the Halal food. The studies discussed lead to a strong belief that the presence of family members, friends, colleagues, teachers, and communities strongly affects the intention to purchase Halal-certified food products from Muslim majority countries in MENA and therefore, hypothesis below is proposed:

H2: Subjective Norm positively affects Purchase Intention

\subsubsection{Perceived Behavioral Control}

Ajzen (1991) defined perceived behavioral control as "people's perception of the ease or difficulty of performing the behavior of interest". Perceived behavioral control is the factor that leads someone to feel an ability to perform a certain behavior. Many Halal marketing researchers also tested the impact of Perceived Behavioral Control on Purchase Intention. A Pakistani study performed by Khan, Asad, and Mehboob (2017) investigated the consumers' intention to purchase Halal endorsed products, and the results indicated that perceived behavioral control shows a significant relationship with Halal endorsed products purchase intention. Perceived behavioral control is also known highly linked with the food safety (environmentally friendliness and the presence of fair trading) and according to the research conducted by Golnaz, Zainulabidin, Nasir, \& Chiew (2010), it showed a strong effect towards the purchase intention towards the Halal food products. Other Halal purchase intention studies also indicated the results that are in line with the two previously mentioned studies (Afendi et al., 2014; Elseidi, 2017; Golnaz, et al., 2010; Haro, 2016; Suki \& Suki, 2015). However, Alam and Sayuti (2011) highlighted that perceived behavioral control was not a factor that dictates the purchase intention. In line with previous studies by Alam and Sayuti (2011), Salehudin and Luthfi (2011), behavioral control was not a factor that influences the purchase intention. Based on the literature review reviewed, it is decided to postulate a hypothesis below:

H3: Perceived Behavioral positively affects Purchase Intention

\subsection{Country of Origin}

Country of origin is also a factor that may highly influence the purchase decision and quite a few studies proved the importance of country of origin in affecting the intention to purchase. Said \& Hassan (2014) proposed the country of origin as one of the determinants of Halal Consumption Congruence (HaCC) in their conceptual paper. Rios, Riquelme, \& Abdelaziz (2014) developed a Halal certification study that investigated the importance of the country of origin. Ishak et al. (2016) indicated that the country of origin was one of the antecedents of consumer halal perceptions and the results showed that the factor highly influenced the purchasing decision. Charlebois, Schwab, Henn, \& Huck (2016) combined an experiment of assessing how consumers perceive food fraud and food labeling inaccuracies related to the region and/or country of origin. The paper proposes a conceptual framework that investigates cultural animosity and the way it influences the purchasing intention 
of the consumers in the Middle East. It proposes a study towards three popular franchises (preferably American). Data were collected and compared for the three franchises with elaboration about the invasion of Iraq in 2003. The level of animosity of each respondent was evaluated and his or her purchasing intentions were analyzed.

The objectives of the present study are to understand the consumers' trust level towards the products from Muslim majority countries in MENA and how strong the influence of the Halal certification in affecting the consumers' purchase decision. The researcher proposes a consumers' trust study that examines the Muslim majority countries in MENA. The study does not have anything to do with the product quality or the Halal integrity of the products. The study is only concerns with the consumers' trust towards the countries if Halal certification is not available in their products. The studied countries are listed in Table 1.

Table 1.

Muslim Majority Countries in MENA (Muslim Population)

\begin{tabular}{rlrrr}
\hline No & Country Name & Muslim Population & Muslim Population (Percentage) & World Percentage \\
\hline 1 & Algeria & $40,560,000$ & 99 & 2.7 \\
2 & Bahrain & 991,892 & 70.2 & $<0.1$ \\
3 & Egypt & $87,300,000$ & 90 & 4.9 \\
4 & Iran & $81,500,000$ & 99.4 & 4.6 \\
5 & Iraq & $38,800,190$ & 99 & 1.9 \\
6 & Jordan & $9,961,123$ & 93.8 & 0.4 \\
7 & Kuwait & $2,636,000$ & 74.1 & 0.2 \\
8 & Lebanon & $3,364,089$ & 54 & 0.2 \\
9 & Libya & $6,325,000$ & 96.6 & 0.4 \\
10 & Morocco & $33,646,788$ & 99 & 2 \\
11 & Oman & $2,427,000$ & 85.9 & 0.2 \\
12 & Palestine & $4,298,000$ & 97.5 & 0.3 \\
13 & Qatar & $1,566,786$ & 77.5 & 0.1 \\
14 & Saudi Arabia & $31,878,000$ & 97.1 & 1.6 \\
15 & Syria & $18,930,000$ & 82.9 & 1 \\
16 & Tunisia & $11,190,000$ & 99.8 & 0.6 \\
17 & Turkey & $80,700,000$ & 99.8 & 4.6 \\
18 & UAE & $4,615,081$ & 76 & 0.2 \\
19 & Yemen & $27,784,498$ & 99 & 1.5 \\
\hline
\end{tabular}

H4: Country of Origin affects the Muslim consumers' trust towards the products without Halal certification

\section{METHODOLOGY}

\subsection{Data}

To ensure that the data collection process runs smoothly, it is important to select the best and the most suitable administration procedure for the questionnaire according to the research needs. There are three administrative procedures of the questionnaire and they are drop-off questionnaire, postal questionnaire, and 
online questionnaire (Saunders, Lewis, \& Thornhill, 2008). Sekaran and Boogie (2010) highlighted that self-administered questionnaire helps the collect a bulk of raw data in a very short period, imposes a relatively cheap cost in the process, as well as ensures the process to be less time consuming compared to the interview method. The data collection was conducted through primary sources while the questionnaires were distributed to the participants. The target population of this study was the Muslim consumers living in Malaysia. The respondents include Malaysians or foreigners as long as the religion of the respondents is Islam and they are 18 years or older (Han, Hsu, \& Lee, 2009; O'Cass, 2000). The areas chosen were decided according to the presence of the Middle Eastern and North African shops in that location and it was thought that the consumers would have a huge exposure towards the food products from Muslim majority countries in MENA. Therefore, the Muslim consumers living in Gombak, Taman Melati, Idaman, Wangsa Maju, Sri Rampai, Bukit Bintang, Chow Kit, Ampang, Masjid Jamek, Serdang, KL Sentral and places around Kuala Lumpur city center were selected as the respondents of this study. The method to collect the data from the respondents was convenience sampling.

In this research, the respondents were Muslim consumers living in Malaysia and their areas were selected based on the exposure of Middle Eastern and North African culture in the locations. It is difficult to determine the number of Muslim consumers in Malaysia who consume food products from Muslim majority in MENA on daily basis. Therefore, a recommendation by Cochran (1963) was selected and the number of parameters in the questionnaire dictated the minimum amount of the respondents. According to Hair et al. (2010), each item needs to at least have five observations. This argument is also supported by a study performed by Baumgartner and Homburg (1996) as they indicated that a research with observation parameter ratio below 5:1 potentially encounters a reliability issue. The questionnaire developed consists of 63 questions and therefore 315 observations were the minimum amount to ensure the success of the research. Five hundred questionnaires were distributed as it was also anticipated to receive incomplete responses, outliers, and missing values. At the end of the day, 417 questionnaires were found to be usable. The respondents consisted of 313 Malaysian respondents and 104 foreign respondents.

\subsection{Method: Structural Equation Modeling (SEM) Analysis}

SEM method is popular for its function to handle a model that consists of many independent and dependent variables. The software used in this research was AMOS 23. SEM is able to handle the effects of many dependent and independent variable in a simultaneous manner and therefore, many researchers recommended the use of SEM (Byrne, 2010; Hair et al., 1998; Hair et al., 2010; Tabachnick \& Fidell, 2012). SEM is considered as a strong statistical software and many researchers are interested to use it due to its function to test hypotheses, independent variables and dependent variables at the same time (Hoe, 2008). It is also imperative to understand that SEM can also model causal relationships between multiple predictors and variables as well as it has an ability to statistically test theoretical framework against the empirical data (Chin, 1998). 
The two important features that make SEM more attractive than other statistical tools include a series of structural equations and diagrammatic representations. Regression, a series of structural equations, is employed to build causal relationships while diagrammatic representations allow the researcher to have the illustration of the research (Hair et al., 2010). The variable in the structural model can also be computed and tested to check the fitness of the model. Once the proposed model achieves a good fit, the model is deemed acceptable, implying that the variables in the model are also deemed justifiable (Byrne, 2010). SEM was chosen as a statistical tool to uncover the research questions of this study and the reason why it was selected was its ability to include many latent constructs. Apart from that, SEM is able to handle theoretical explanation of other multivariate techniques as it consists of multiple regression, factor analysis, and path analysis (Hair et al., 2010).

\section{RESULTS AND DATA ANALYSIS}

\subsection{Demographics}

The 417 usable questionnaires were later compiled and processed using SPSS. The descriptive analysis was also performed. As can be seen in Table 2, the respondent profile consisted of 233 female respondents (55.9\%) and 184 male respondents $(44.1 \%)$. The range of 23 to 30 years dominated the population with 188 respondents $(45.1 \%)$, followed by 18 to 22 years that consisted of 118 respondents $(28.3 \%)$. The next largest group was 31 to 40 years with the total of 75 respondents $(18 \%)$. The age group of $41-50$ and over 50 consisted of 22 respondents (5.3\%) and 14 respondents $(3.4 \%)$ respectively.

As far as marital status is concerned, 129 (30.9\%) of the respondents were married and $280(67.1 \%)$ were single. The remaining respondents $(8,1.9 \%)$ identified themselves as others. The study was participated by 104 Non-Malaysians $(24.9 \%)$ and 313 Malaysians (75.1\%). In terms of Islamic Madhab, 326 of the respondents $(78.2 \%)$ were the followers of Imam Shafi'i, while 39 of them were the followers of Imam Hanafi (9.4\%). The rest of the respondents were following Imam Maliki (15 respondents, 3.6\%), and Imam Hanbali (6 respondents, 1.4\%). 20 respondents (4.8\%) were not sure about their own Madhabs and 11 respondents (2.6\%) followed other Madhabs.

Most of the respondents belonged to the Bachelor's Degree and Master's Degree holders with 182 respondents (43.6\%) and 121 respondents (29.0\%) respectively. The other participants were either high school graduates, Diploma holders, or Ph. D. holders. Ten of the participants filled out their educational background as others.

The monthly incomes of the respondents ranged from below RM 1000 to more than RM 5000. Most of the respondents, 180 out of 417 respondents (43.2\%), fell into the category of below RM 1000 as some of the respondents were still pursuing their education. The second largest group was the RM 1001 to RM 2000 earners with 74 respondents $(17.7 \%)$ while the third largest group was the RM 5000 earners with 61 respondents $(14.6 \%)$. The remaining respondents earned RM 2001 to RM 3000 (42 respondents, 10.1\%), RM 3001 - RM 4000 (30 respondents, $7.2 \%$ ) and RM 4001 to (30 respondents, $7.2 \%$ ). The complete summary of the demographic description can be seen in Table 2. 
Table 2.

Demographic Description

\begin{tabular}{|c|c|c|c|}
\hline \multirow{2}{*}{ Demographic Description } & & \multicolumn{2}{|c|}{ Research Sample $(\mathrm{n}=417)$} \\
\hline & & $\begin{array}{l}\text { Number of } \\
\text { Respondents }\end{array}$ & Percentage \\
\hline \multirow[t]{2}{*}{ Gender } & Male & 184 & 44.12 \\
\hline & Female & 233 & 55.88 \\
\hline \multirow[t]{5}{*}{ Age } & $18-22$ & 118 & 28.30 \\
\hline & $23-30$ & 188 & 45.08 \\
\hline & $31-40$ & 75 & 17.99 \\
\hline & $41-50$ & 22 & 5.28 \\
\hline & Over 50 & 14 & 3.36 \\
\hline \multirow[t]{3}{*}{ Marital Status } & Single & 280 & 67.15 \\
\hline & Married & 129 & 30.94 \\
\hline & Other & 8 & 1.92 \\
\hline \multirow[t]{6}{*}{ Education Background } & Highschool & 36 & 8.63 \\
\hline & Diploma & 34 & 8.15 \\
\hline & Bachelor's Degree & 182 & 43.65 \\
\hline & Master's Degree & 121 & 29.02 \\
\hline & Ph. D. & 34 & 8.15 \\
\hline & Other & 10 & 2.40 \\
\hline \multirow[t]{6}{*}{ Monthly Income } & Below RM1000 & 180 & 43.17 \\
\hline & RM1001-2000 & 74 & 17.75 \\
\hline & RM2001-3000 & 42 & 10.07 \\
\hline & RM3001-4000 & 30 & 7.19 \\
\hline & RM4001-5000 & 30 & 7.19 \\
\hline & More than RM5000 & 61 & 14.63 \\
\hline \multirow[t]{6}{*}{ Islamic Madhab } & Imam Shafi'i & 326 & 78.18 \\
\hline & Imam Hanafi & 39 & 9.35 \\
\hline & Imam Maliki & 15 & 3.60 \\
\hline & Imam Hanbali & 6 & 1.44 \\
\hline & Other & 11 & 2.64 \\
\hline & I am not Sure & 20 & 4.80 \\
\hline \multirow[t]{2}{*}{ Nationality } & Malaysian & 313 & 75.06 \\
\hline & Non-Malaysia & 104 & 24.94 \\
\hline
\end{tabular}




\subsection{Country of Origin Study}

Table 3.

Consumers' Trust towards the Muslim Majority Countries in MENA (Mean)

\begin{tabular}{llcccccc}
\hline No & Country Name & $\begin{array}{c}\text { Not } \\
\text { Trustworthy/ } \\
\text { Not Familiar }\end{array}$ & $\begin{array}{c}\text { Slightly } \\
\text { Trustworthy }\end{array}$ & Trustworthy & $\begin{array}{c}\text { Very } \\
\text { Trustworthy }\end{array}$ & $\begin{array}{c}\text { Extremely } \\
\text { Trustworthy }\end{array}$ & Mean \\
\hline 1 & Saudi Arabia & 25 & 30 & 108 & 115 & 135 & 3.74 \\
2 & Palestine & 33 & 34 & 117 & 113 & 116 & 3.59 \\
3 & Turkey & 26 & 44 & 126 & 113 & 104 & 3.54 \\
4 & Jordan & 33 & 39 & 115 & 131 & 95 & 3.52 \\
5 & UAE & 35 & 41 & 119 & 126 & 92 & 3.48 \\
6 & Qatar & 43 & 35 & 113 & 131 & 91 & 3.46 \\
7 & Kuwait & 42 & 31 & 130 & 116 & 94 & 3.46 \\
8 & Syria & 41 & 40 & 134 & 111 & 87 & 3.39 \\
9 & Yemen & 44 & 42 & 126 & 113 & 88 & 3.38 \\
10 & Egypt & 48 & 43 & 150 & 106 & 66 & 3.24 \\
11 & Oman & 61 & 36 & 139 & 121 & 56 & 3.18 \\
12 & Libya & 56 & 50 & 140 & 109 & 58 & 3.15 \\
13 & Tunisia & 63 & 40 & 157 & 110 & 43 & 3.07 \\
14 & Morocco & 59 & 52 & 151 & 107 & 44 & 3.06 \\
15 & Bahrain & 70 & 43 & 158 & 97 & 45 & 3.01 \\
16 & Iraq & 71 & 52 & 159 & 89 & 42 & 2.95 \\
17 & Lebanon & 77 & 62 & 153 & 86 & 35 & 2.85 \\
18 & Algeria & 92 & 59 & 145 & 86 & 31 & 2.77 \\
19 & Iran & 90 & 70 & 144 & 74 & 35 & 2.74 \\
\hline
\end{tabular}

The respondents were asked to rate their trust level towards the food products from the MENA countries if Halal certification is not available. The five options include Not Trustworthy/Not Familiar, Slightly Trustworthy, Trustworthy, Very Trustworthy, and Extremely Trustworthy. As can be seen in Table 3, Saudi Arabia was the country that the respondents found to be the most trustworthy with the mean of 3.74. It was then followed by Palestine, Turkey, Jordan and United Arab Emirates (UAE) with the mean of 3.59, 3.54, 3.52 and 3.48 respectively. 
Table 4.

Country of Origin - Low Trust Level Analysis

\begin{tabular}{rlccccc}
\hline No & Country Name & $\begin{array}{c}\text { Not } \\
\text { Trustworthy/Not } \\
\text { Familiar }\end{array}$ & Percentage & $\begin{array}{c}\text { Slightly } \\
\text { Trustworthy }\end{array}$ & Percentage & $\begin{array}{c}\text { Low Trust } \\
\text { Percentage }\end{array}$ \\
\hline 1 & Iran & 90 & 21.79 & 70 & 16.95 & 38.74 \\
2 & Algeria & 92 & 22.28 & 59 & 14.29 & 36.56 \\
3 & Lebanon & 77 & 18.64 & 62 & 15.01 & 33.66 \\
4 & Iraq & 71 & 17.19 & 52 & 12.59 & 29.78 \\
5 & Bahrain & 70 & 16.95 & 43 & 10.41 & 27.36 \\
6 & Morocco & 59 & 14.29 & 52 & 12.59 & 26.88 \\
7 & Libya & 56 & 13.56 & 50 & 12.11 & 25.67 \\
8 & Tunisia & 63 & 15.25 & 40 & 9.69 & 24.94 \\
9 & Oman & 61 & 14.77 & 36 & 8.72 & 23.49 \\
10 & Egypt & 48 & 11.62 & 43 & 10.41 & 22.03 \\
11 & Yemen & 44 & 10.65 & 42 & 10.17 & 20.82 \\
12 & Syria & 41 & 9.93 & 40 & 9.69 & 19.61 \\
13 & Qatar & 43 & 10.41 & 35 & 8.47 & 18.89 \\
14 & UAE & 35 & 8.47 & 41 & 9.93 & 18.40 \\
15 & Kuwait & 42 & 10.17 & 31 & 7.51 & 17.68 \\
16 & Jordan & 73 & 6.99 & 39 & 9.44 & 17.43 \\
17 & Turkey & 26 & 4.99 & 34 & 8.23 & 16.22 \\
18 & Palestine & 33 & 30 & 7.26 & 13.32 \\
19 & Saudi Arabia & 25 & & & &
\end{tabular}

Table 4 shows the low trust analysis and it depicts the percentage of the consumers who did not display the high level of trust towards certain countries if Halal certification is not available in their food products. Algeria was a country that they found to be the least trustworthy/least familiar as $92(22.28 \%)$ respondents said that the country was not trustworthy or familiar, while Iran, Lebanon, Iraq, and Bahrain followed Algeria with 90 respondents (21.79\%), 77 respondents (18.64\%), 71 respondents $(17.19 \%)$ and 70 respondents $(16.95 \%)$. Even the most trustworthy country (Saudi Arabia) had 25 respondents who believed it to be not trustworthy $(6.05 \%)$. The results do not have anything to do with the product quality, process improvement or cleanliness as the results are just pure consumers' perception. The number of the respondents also reflects potential sales as people who do not trust will highly unlikely purchase the products and therefore, it is crucial for the MENA countries to attach the Halal certification in their products, so they will have an opportunity to be huge industry players in the Halal industry as well as the food industry. 


\subsection{Exploratory Factor Analysis (EFA)}

The EFA in this research was applied to all the factors involved in the main research model. The factors analyzed were Attitude, Subjective Norm, Perceived Behavioral Control, and Purchase Intention. The process was performed using SPSS 23 software and principal component extraction technique and varimax rotation were the methods employed. Some assumptions considered during the analysis were Kaiser-Meyer-Olkin (KMO) and Bartlett's test of Sphericity. Initially, the Kaiser-Meyer-Olkin (KMO) measure of sampling adequacy was investigated. The minimum threshold of $\mathrm{KMO}$ value is 0.7 , and the value of $\mathrm{KMO}$ of this research was 0.960 (as can be seen in Table 5), which indicated that the data was good enough for factor analysis purpose. With $p<0.001$, Bartlett's test of Sphericity was also found to be significant. The value meant that there was an adequate correlation between the items/components.

Table 5.

KMO and Bartlett's Test

\begin{tabular}{llr}
\hline Kaiser-Meyer-Olkin Measure of Sampling Adequacy. & $\mathbf{0 . 9 6}$ \\
\hline Bartlett's Test of Sphericity & Approx. Chi-Square & 9404.409 \\
& df & 351 \\
Sig. & 0 \\
\hline
\end{tabular}

Apart from that, the commonalities were also investigated and the minimum threshold is 0.5, as recommended by Hair et al. (2010). The underlying assumptions of EFA were investigated and the method used was Principal Component Analysis with varimax rotation. The minimum threshold is 0.5 and none of the items were removed. The EFA process provided a result that showcased four components with the Kaiser-Guttman retention rule of eigenvalues more than 1 . The cumulative variance is expected to reach the threshold of $60 \%$ and the cumulative variance explained by the six factors was 70.740. The four factors explained were Attitude, Subjective Norm, Perceived Behavioral Control, and Purchase Intention. 
Table 6.

Rotated Component Matrix

\begin{tabular}{|c|c|c|c|c|c|}
\hline Factor Name & Eigenvalue & $\begin{array}{c}\text { Percentage of } \\
\text { Variance }\end{array}$ & $\begin{array}{l}\text { Cumulative } \\
\text { Variance }\end{array}$ & Item Name & $\begin{array}{c}\text { Factor } \\
\text { Loadings }\end{array}$ \\
\hline \multirow[t]{7}{*}{ Purchase Intention } & 14.051 & 19.241 & 19.241 & PI5 & 0.794 \\
\hline & & & & PI3 & 0.776 \\
\hline & & & & PI6 & 0.756 \\
\hline & & & & PI4 & 0.75 \\
\hline & & & & PI2 & 0.748 \\
\hline & & & & PI1 & 0.712 \\
\hline & & & & PI7 & 0.702 \\
\hline \multirow[t]{6}{*}{ Attitude } & 2.069 & 18.154 & 37.395 & AT2 & 0.81 \\
\hline & & & & AT1 & 0.791 \\
\hline & & & & AT6 & 0.755 \\
\hline & & & & AT4 & 0.725 \\
\hline & & & & AT3 & 0.706 \\
\hline & & & & AT5 & 0.696 \\
\hline \multirow[t]{7}{*}{ Subjective Norm } & 1.699 & 17.55 & 54.945 & SN3 & 0.817 \\
\hline & & & & SN4 & 0.792 \\
\hline & & & & SN5 & 0.762 \\
\hline & & & & SN6 & 0.676 \\
\hline & & & & SN7 & 0.658 \\
\hline & & & & SN1 & 0.594 \\
\hline & & & & SN2 & 0.591 \\
\hline Perceived Behavioral & 1.28 & 15.795 & 70.74 & PB4 & 0.769 \\
\hline \multirow[t]{6}{*}{ Control } & & & & PB2 & 0.754 \\
\hline & & & & PB3 & 0.75 \\
\hline & & & & PB7 & 0.712 \\
\hline & & & & PB5 & 0.66 \\
\hline & & & & PB1 & 0.6 \\
\hline & & & & PB6 & 0.482 \\
\hline
\end{tabular}

Purchase Intention was the factor that accounted for the highest percentage of the variance explained as it was responsible for $19.241 \%$ and the Eigenvalue was 14.051 . Attitude accounted for $18.154 \%$ of the variance explained (Eigenvalue $=2.069$ ), Subjective Norm accounted for $17.550 \%$ of the variance explained (Eigenvalue $=1.699$ ), and Perceived Behavioral Control accounted for $15.795 \%$ of the variance explained $($ Eigenvalue $=1.280)$ 
The analysis generated four dimensions that had various underlying items. Purchase Intention, Subjective Norm and Perceived Behavioral Control had 7 items, while Attitude consisted of 6 items. The table 6 shows the rotated component matrix along with the Eigenvalues and variance explained for each component. Once the EFA test was completed, the reliability test of the resulted factors was performed as many scholars suggested that the Cronbach's alpha is a good method to do so (Hair et al., 2010; Kline, 2005; Schumacker \& Lomax, 2010). Sekaran \& Boogie (2010) suggested that Cronbach's Alpha should at least reach 0.7 thresholds and all the four factors generated Cronbach's Alpha above 0.7. The Cronbach's Alpha values generated were ranging from 0.879 to 0.946 as can be seen in Table 7 below.

Table 7.

Reliability Coefficient of the Extracted Factors

\begin{tabular}{lccc}
\hline Factor & Number of Cases & Number of Items & Cronbach's Alpha \\
\hline Attitude & 417 & 6 & 0.928 \\
Subjective Norm & 417 & 7 & 0.929 \\
Perceived Behavioral Control & 417 & 7 & 0.879 \\
Purchase Intention & 417 & 7 & 0.946 \\
\hline
\end{tabular}

\subsection{Confirmatory Factor Analysis (CFA)}

Confirmatory Factor Analysis of the measurement model indicates the relationship between the observed indicators and the latent constructs. The latent constructs are intercorrelated with each other. AMOS 23 was used as a software to test the CFA. Squared multiple correlations exhibited by all the measurement items were found to be higher than 0.5 and this indicated a good reliability level. There were 27 observed indicators to estimate the model fit. Upon the completion, CFA was conducted, and the results of the measurement indicated a fit to the sample data. The CFI was 0.948, it was above the minimum threshold, and the RMSEA was 0.061, which was below the acceptable level of 0.08. Overall, the results ranged within the acceptable levels (as can be seen in Table 8) and it can be concluded that the values represented an acceptable model fit.

Table 8.

Fit Indices of Measurement Model

\begin{tabular}{llcc}
\hline X2 & df & CFI & RMSEA \\
\hline 794.442 & 309 & 0.948 & 0.061 \\
\hline
\end{tabular}

\subsection{Reliability and Validity}

Reliability and validity are the two important factors that need investigation before proceeding to the causal relationships testing. Cronbach's Alpha and composite reliability were determined to ensure that the research instrument 
achieved a stability and consistency. The Cronbach's Alpha values for the overall instrument and individual construct were shown in Table 7. Hair et al. (2010) also recommended another type of reliability test that is called composite reliability (CR). The results indicated that all the CR values were higher than 0.7 , meaning all the values showcased a high reliability. For the validity test, Hair et al. (2010) suggested that it is crucial to calculate the following: Composite Reliability (CR), Average Variance Explained (AVE), Maximum Shared Squared Variance (MSV) and Average Shared Squared Variance (ASV) in order to reach good convergent validity and discriminant validity (construct validity). To achieve convergent validity, Hair et al. (2010) recommended that CR must be greater than AVE and AVE must be greater than 0.5 . While to reach good discriminant validity, MSV must be below AVE, and AVE must be higher than ASV. It can be seen from Table 9 that the resulted values have achieved the criteria for reliability, as well as the convergent validity and discriminant validity.

Table 9.

Reliability and Validity

\begin{tabular}{lcccc}
\hline Factor & CR & AVE & MSV & MaxR(H) \\
\hline Purchase Intention & 0.946 & 0.714 & 0.521 & 0.948 \\
Attitude & 0.928 & 0.684 & 0.537 & 0.931 \\
Subjective Norm & 0.929 & 0.652 & 0.537 & 0.941 \\
Perceived Behavioral Control & 0.879 & 0.512 & 0.48 & 0.887 \\
\hline
\end{tabular}

\subsection{Structural Equation Modeling}

The structural model developed in this research consists of four major constructs namely; Halal Certification Motives, Attitude, Subjective Norms, Perceived Behavioral Control and Purchase Intention (please see Figure 1). The latent variables are connected with single arrows that indicate causal relationships between them between exogenous and endogenous variables. Purchase Intention is an endogenous variable while Attitude, Subjective Norms, and Perceived Behavioral Control are exogenous variables. The items for the questionnaire are represented with the boxes. The proposed model was analyzed using some fit measures namely; normed chi-square, comparative fit index (CFI), and the root mean square error of approximation (RMSEA). Many researchers have recommended the previously mentioned measures (Byrne, 2010; Hair et al., 2010; Kline, 2005). Due to its sensitivity to the sample size, normed chi-square was applied instead of the chi-square test. Moreover, the path coefficients were also analyzed for their statistical significance at $p<0.05$.

The structural model tested came with results of the acceptable goodness of fit indices. Therefore, it can be concluded that the hypothesized model fits the investigated data quite strongly. The normed chi-square value was 2.975 and it was lower than the suggested threshold value of 5 . The value of RMSEA was 0.069 , which was also below the maximum cut-off point of 0.08 . Therefore, it can be concluded all the results showed a good fit of the suggested model (as can be seen in Table 10). 
The hypotheses developed for the theoretical framework has three structural paths. All three structural paths were found to be statistically significant at $p<0.05$ level.

Figure 1.

Baseline Structural Model

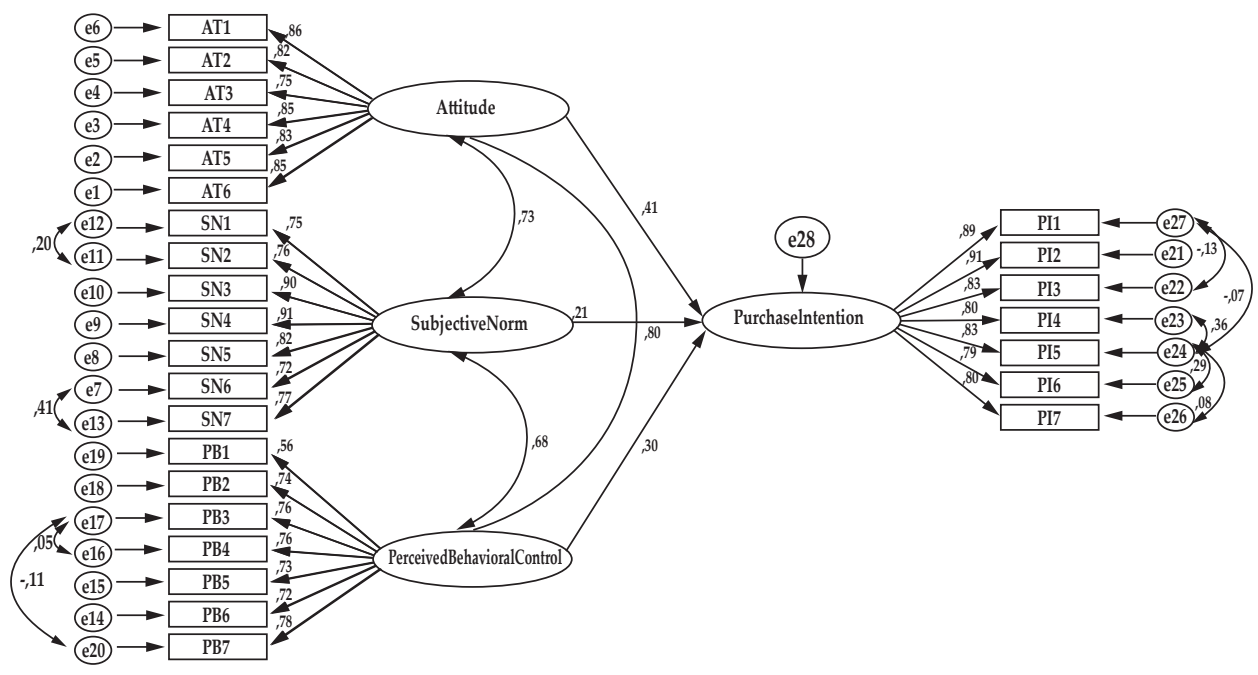

Table 10.

Fit Indices of Structural Model

\begin{tabular}{llccc}
\hline $\mathbf{X} 2$ & df & X2/df & CFI & RMSEA \\
\hline 919.141 & 309 & 2.975 & 0.934 & 0.069 \\
\hline
\end{tabular}

\subsubsection{Hypothesis H1: Attitude will positively affect Purchase Intention}

Based on Table 11, the structural path between Attitude and Purchase Intention was statistically significant at $p<0.05$. Other estimates calculated include standardized regression weight of 0.414 , standard error of 0.061 , and the critical ratio of 7.479 . The positive relationship between Attitude and Purchase intention indicated that the stronger the Muslim consumers' attitude towards the Halal-certified products from the Muslim majority countries in MENA, indicating higher chances for them to eventually purchase the products. The results were in the same direction as the previous studies (Afendi et al., 2014; Elseidi, 2017; Hasnah Hassan, 2014; Jaafar et al., 2013; Mohd Suki \& Mohd Suki, 2015; Widodo, 2013; Wilson, Liu, Lada, Tanakinjal, \& Amin, 2010). Therefore, it is decided to reject the null hypothesis, and it is concluded that Attitude positively affects the Purchase Intention.

4.6.2. Hypothesis H2: Subjective Norm will positively affect Purchase Intention Based on Table 11, the structural path between Subjective Norm and Purchase Intention was statistically significant at $p<0.05$. Other estimates calculated include standardized regression weight of 0.206 , standard error of 0.074 , and the critical 
ratio of 3.43. The positive relationship between Subjective Norm and Purchase Intention revealed that the stronger the influence and perception of the people around the Muslim consumer towards the Halal-certified products from the Muslim majority countries in MENA, the more likely they purchase the products. The results are in line with the previous studies (Afendi et al., 2014; Elseidi, 2017; Omar, Jaafar, \& Osman, 2011; Salehudin \& Luthfi, 2011a; Shah Alam \& Mohamed Sayuti, 2011). Therefore, it is decided to reject the null hypothesis, and it is summarized that Subjective Norm positively affects the Purchase Intention.

\subsubsection{Hypothesis H3: Perceived Behavioral Control will Positively Affect Purchase Intention}

Many purchase intention study towards the Halal products expressed a strong relationship between Perceived Behavioral Control and Intention (Afendi et al., 2014; Elseidi, 2017; Golnaz, et al., 2010; Haro, 2016; Suki \& Suki, 2015). The results of the present research were in line with the mentioned studies. Based on Table 11, the structural path between Perceived Behavioral Control and Purchase Intention was statistically significant at $p<0.05$. Other estimates calculated include standardized regression weight of 0.297 , standard error of 0.065 , and the critical ratio of 5.679 . Therefore, it is decided to reject the null hypothesis, and it is concluded that Perceived Behavioral Control is positively correlated with Purchase Intention.

\subsubsection{Summary of Hypotheses Testing}

Table 11.

Estimates of Hypothesized Model

\begin{tabular}{lcccc}
\hline Path & Estimate & Standard Error & Critical Ratio & P \\
\hline Purchase Intention <--- Attitude & 0.414 & 0.061 & 7.479 & $* * *$ \\
Purchase Intention <--- Subjective Norm & 0.206 & 0.074 & 3.43 & $* * *$ \\
Purchase Intention <--- Perceived & 0.297 & 0.065 & 5.679 & $* * *$ \\
Behavioral Control & & & & \\
\hline
\end{tabular}

\section{RESULTS AND DATA ANALYSIS}

\subsection{Conclusion}

The research offers an insight on the determinant factors that influence the purchase intention towards Halal-certified food products from Muslim majority countries in MENA. Muslim consumers living in Malaysia were the respondents of the study. Theory of Planned Behavior (TPB) was used as a platform to predict the consumers' intention to purchase the Halal certified products. Attitude, Subjective Norm, and Perceived Behavioral Control were found to have a positive relationship with Purchase Intention and the results were statistically significant at $p<0.05$. The results showed the importance of the Halal certification and the presence of the Halal certification improves the interest of the Muslim consumers 
to conduct a purchase. The country of origin study showed that the food products from Algeria, followed by Iran, Lebanon, Iraq, and Bahrain were deemed to be the least trustworthy if Halal certification is not present according to the Muslim consumers in Malaysia. The results indicated that the presence of Halal certification is important and will be profitable for the food industry players in the MENA region. The presence of Halal certification is deemed important for all countries, especially those that received low scores in the country of origin study.

\subsection{Recommendation}

The research was designed to investigate the purchase behavior of Muslim consumers living in Malaysia. The purchase intention study was finalized, and most respondents reacted positively towards the idea of Halal-certified food products from MENA countries. However, respondents from a different region or a different country may have different reactions as they are exposed to certain cultures and they are dealing with some certain situations. Most countries in MENA region consist of almost 100\% Muslims in their populations, and somehow it will be interesting to learn whether their Muslim consumers also have the same level of excitement or concern as the Muslim consumers in Malaysia.

Apart from that, there are some Non-Muslim majority countries and a small fraction of Muslim consumers also live there. A study in the mentioned countries is also imperative as the respondents from the non-Muslim majority countries are likely to have a different type of behavior/trend compared to the Muslim consumers in Malaysia. There is a potential cross-cultural study that investigates an almost $100 \%$ Muslim majority country (homogenous Muslim population), a culturally mixed country where the Muslim presence is reasonably strong, such as Lebanon or Malaysia, and a country where the Muslim consumers are a complete minority, like Taiwan, Australia, New Zealand, USA and many countries in Europe. It is also believed that the addition of more factors to influence Purchase Intention will make the research significantly richer and more interesting. Animal Welfare, Health, Food Safety, and Religiosity are some of the factors that potentially provide interesting future studies.

For the practitioners, regulators, and the central bank, it is important for them to be the means that ensures the presence of Halal certification in the food products. The presence of Halal certification has proved to catapult sales and to be the interest of both Muslim consumers and non-Muslim consumers due to high relationship between Halal certified food products and good quality. Halal certified products can also increase the export of the MENA countries as Halal certified food products are on high demand overseas. The increased export will highly impact on GDP and foreign currency reserve. This may eventually lead to the presence of the new investors in the near future. 


\section{REFERENCES}

Abd-Rahman, A., Asrarhaghighi, E., \& Ab Rahman, S. (2015). Consumers and Halal Cosmetic Products-Knowledge, Religiosity, Attitude and Intention. Journal of Islamic Marketing, 6(1), 148-163. https://doi.org/http://dx.doi.org/10.1108/JEIM07-2014-0077

Afendi, N. A., Azizan, F. L., \& Darami, A. I. (2014). Determinants of Halal Purchase Intention: Case in Perlis. International Journal of Business and Social Research, 4(5), 118-123.

Afsari, A., Suryantini, A., \& Mulyo, J. H. (2017). The Influence of Attitude, Subjective Norm, and Perceived Behavioural Control Toward Snack Consumer Behaviour in Halal Labeling in Yogyakarta. Ilmu Pertanian (Agricultural Science), 2(1), 2934.

Ajzen, I. (1991). The Theory of Planned Behavior. Organizational Behavior and Human Decision Processes, 50, 179-211. https://doi.org/10.1016/0749-5978(91)90020-T

Ajzen, I. (2015). Consumer Attitudes and Behavior: The Theory of Planned Behavior Applied to Food Consumption Decisions. Rivivista Di Economia Agraria, 2(AnnoLXX), 121-138. https://doi.org/10.13128/REA-18003

Ajzen, I., \& Fishbein, M. (1975). Belief, Attitude, Intention and Behavior: An Introduction to Theory and Research.

Ajzen, I., \& Fishbein, M. (1980). Understanding Attitudes and Predicting Social Behavior. Englewood Cliffs, NJ: Prentice-Hal.

Akgündüz, A. (2012). Helal g1da meselesi, Avrupa'da helal gıda problemleri ve çözüm yolları. In In İhracat İçin Helal Sertifikası Sempozyumu Bildirileri, Güney Marmara Kalkınma Ajansı. Balıkesir (pp. 1-14).

Al-Swidi, A., Huque, S. M. R., Hafeez, M. H., \& Shariff, M. N. M. (2014). The Role of Subjective Norms in Theory of Planned Behavior in the Context of Organic Food Consumption. British Food Journal, 116(10), 1561-1580. https:// doi.org/10.1108/BFJ-05-2013-0105

Alam, S. S., \& Sayuti, N. M. (2011). Applying the Theory of Planned Behavior (TPB) in Halal Food Purchasing. International Journal of Commerce and Management, 21(1), 8-20. https://doi.org/10.1108/10569211111111676

Alijani, E. (2015). Iran's Underground Restaurants Serve Up Pork, Wine and a Pinch of Freedom. Retrieved from http://observers.france24.com/en/20150427iran-underground-restaurants-pork-wine-freedom

Aossey, J. (2009). Point to ponder: How Genuine is Halal Stamp? Retrieved from http://www.arabnews.com/node/319588

Arvola, A., Vassallo, M., Dean, M., Lampila, P., Saba, A., Lähteenmäki, L., \& Shepherd, R. (2008). Predicting Intentions to Purchase Organic Food: The Role of Affective and Moral Attitudes in the Theory of Planned Behaviour. Appetite, 50(2-3), 443-454.

Aslan, I. (2016). Measuring Halal Awareness at Bingol City. Journal of Social Sciences, 5(3), 340-355. https://doi.org/10.25255/jss.2016.5.3.340.355

Aziz, Y. A., Nyen, \&, \& Chok, V. (2013). The Role of Halal Awareness, Halal Certification, and Marketing Components in Determining Halal Purchase Intention Among Non-Muslims in Malaysia: A Structural Equation Modeling Approach. Journal of International Food E Agribusiness Marketing, 25(1), 1-23. https://doi.org/10.1080/08974438.2013.723997 
Batu, A. (2012). Türkiye'de Helal (Mahzursuz) Gida ve Helal Belgelendirme Sistemi. TEKNOLOJIK ARAŞTIRMALAR, 7(1), 51-61.

Batu, A., \& Regenstein, J. M. (2014). Halal Food Certification Challenges and Their Implications for Muslim Societies Worldwide. Turkish Studies - International Periodical For The Languages, Literature and History of Turkish or Turkic, 9(11), 111-130.

Baumgartner, H., \& Homburg, C. (1996). Applications of Structural Equation Modeling in Marketing and Consumer Research: A Review. International Journal of Research in Marketing. International Journal of Research in Marketing, 13, 139-161.

Belamri, R. (2010). Algerian Fatwa Prohibits Indian Meat. Retrieved from https:// www.alarabiya.net/articles/2010/08/05/115762.html

Bonne, K., \& Verbeke, W. (2008). Religious Values Informing Halal Meat Production and the Control and Delivery of Halal Credence Quality, 35-47. https://doi. org/10.1007/s10460-007-9076-y

Byrne, B. M. (2010). Structural Equation Modeling with AMOS. Structural Equation Modeling (Vol. 22). https://doi.org/10.4324/9781410600219

Charlebois, S., Schwab, A., Henn, R., \& Huck, C. W. (2016). Food Exploratory Study for Measuring Consumer Perception towards Mislabeled Food Products and Influence on Self-Authentication Intentions. Trends in Food Science and Technology, 50, 211-218. https://doi.org/10.1016/j.tifs.2016.02.003

Cochran, W. G. (1963). Sampling Technique (2nd Editio). New York: John Wiley and Sons Inc.

Cochrane, P. (2016). Lebanon's Halal Food Sector in Need of National-Level Oversight to Boost Market Confidence and Exports. Retrieved from https:// www.salaamgateway.com/en/story/lebanons_halal_food_sector_in_need_ of_nationallevel_oversight_to_boost_market_confidence_and_exportsSALAAM24092016061614/

Dean, M., Raats, M., \& Shepherd, R. (2008). Moral Concerns and Consumer Choice of Fresh and Processed Organic Foods. Journal of Applied Social Psychology. 38. 2088 - 2107. 10.1111/j.1559-1816.2008.00382.x. Journal of Applied Social Psychology, 38(8), 2088-2107.

Doosti, A., Ghasemi, P. D., \& Rahimi, E. (2014). Molecular Assay to Fraudidentification of Meat Products. Journal of Food Science and Technology, 51(1), 148-152.

E. Rios, R., E. Riquelme, H., \& Abdelaziz, Y. (2014). Do Halal Certification Country of Origin and Brand Name Familiarity Matter? Asia Pacific Journal of Marketing and Logistics, 26(5), 665-686. https://doi.org/10.1108/APJML-03-2014-0046

Elseidi, R. I. (2017). Determinants of Halal Purchasing Intentions: Evidences from UK. Journal of Islamic Marketing. https://doi.org/https://doi.org/10.1108/JIMA02-2016-0013

Eves, A., \& Cheng, L. (2007). Cross-cultural Evaluation of Factors Driving Intention to Purchase New Food Products-Beijing, China and South-East England. International Journal of Consumer Studies, 31(4), 410-417.

Golnaz, R., Zainalabidin, M., Mad Nasir, S., \& Eddie Chiew, F. C. (2010). Nonmuslims' Awareness of Halal Principles and Related Food Products in Malaysia. International Food Research Journal, 17(3), 667-674. https://doi. org/10.1108/JIMA-04-2014-0033 
Golnaz, R., Zainulabidin, M., Mad Nasir, S., \& Eddie Chiew, F. C. (2010). NonMuslim Awareness of Halal Principle and Related Food Products in Malaysia. International Food Research Journal, 17, 667-674. https://doi.org/10.1108/JIMA04-2014-0033

Govind, R. Y., \& Pathak, S. (2016). Intention to Purchase Organic Food among Young Consumers: Evidences from a Developing Nation. Appetite, 96(1), 122128.

Hair, J. F., Black, W. C., Babin, B. J., \& Anderson, R. E. (2010). Multivariate Data Analysis. Vectors. https://doi.org/10.1016/j.ijpharm.2011.02.019

Han, H., Hsu, L.-T. (Jane), \& Lee, J.-S. (2009). Empirical Investigation of the Roles of Attitudes towards Green Behaviors, Overall Image, Gender, and Age in Hotel Customer's Eco-Friendly Decision-Making Process. International Journal of Hospitality Management, 28(4), 519-528.

Hanzaee, K. H., \& Ramezani, M. R. (2011). Intention To Halal Products In The World Markets. Interdisciplinary Journal of Research in Business, 1(5), 1-7.

Haro, A. (2016). Understanding Tpb Model, Availability, and Information on Consumer Purchase Intention for Halal Food. International Journal of Business and Commerce (ISSN:, 5(8), 47-56.

Hasnah Hassan, S. (2014). The Role of Islamic Values on Green Purchase Intention. Journal of Islamic Marketing, 5(3), 366-378. https://doi.org/10.1108/JIMA-112013-0080

Ireland, J., \& Abdollah Rajabzadeh, S. (2011). UAE Consumer Concern about Halal Products. Journal of Islamic Marketing, 2(3), 274-283. https:/doi. org/10.1108/17590831111164796

Ishak, S., Awang, A. H., Hussain, M. Y., Ramli, Z., Md Sum, S., Saad, S., \& Abd Manaf, A. (2016). A Study on the Mediating Role of halal Perception: Determinants and Consequence Reflections. Journal of Islamic Marketing, 7(3), 288-302. https://doi.org/10.1108/JIMA-02-2015-0010

Jaafar, S. N., Lalp, P. E., \& Naba, M. M. (2013). Consumers' Perceptions, Attitudes and Purchase Intention towards Private Label Food Products in Malaysia. Asian Journal of Business and Management Sciences, 2(8), 73-90. Retrieved from http://www.ajbms.org/articlepdf/8ajbms2012282721.pdf

Karaman, H. (2012). Helal gida. Retrieved from http://www.gidahareketi.org/ Helal-Gida-(1-2)-585-yazisi.aspx.

Khalek, A. A., \& Ismail, S. H. S. (2015). Why Are We Eating Halal - Using the Theory of Planned Behavior in Predicting Halal Food Consumption among Generation Y in Malaysia. International Journal of Social Science and Humanity, 5(7), 608-612. https://doi.org/10.7763/IJSSH.2015.V5.526

Khan, M. M., Asad, H., \& Mehboob, I. (2017). Investigating the Consumer Behavior for Halal Endorsed Products: Case of An Emerging Muslim Market. Journal of Islamic Marketing, 8(4), 625-641. https://doi.org/10.1108/JIMA-09-2015-0068

Kline, R. (2005). Principles and Practice of Structural Equation Modeling (2nd edition) (2nd Editio). New York: Guilford Press.

Lada, S., Tanakinjal, G. H., \& Amin, H. (2010). Predicting Intention to Choose Halal Products using Theory of Reasoned Action. International Journal of Islamic and Middle Eastern Finance and Management, 2(1), 66-76. https:/doi. org/10.1108/17538390910946276 
Latif, I. A., Mohamed, Z., Sharifuddin, J., \& Mahir, A. (2016). A Comparative Analysis of Global Halal Certification Requirements A Comparative Analysis of Global Halal, 4446(January). https://doi.org/10.1080/10454446.2014.921869

Liow, R. J. (2012). Marketing Halal, Creating New Economy, New Wealth. Petaling Jaya: MPH Group Publishing.

Mohd Suki, N., \& Abang Salleh, A. S. (2016). Does Halal image Strengthen Consumer Intention to Patronize Halal stores? Journal of Islamic Marketing, 7(1), 120-132. https://doi.org/10.1108/JIMA-12-2014-0079

Mohd Suki, N., \& Mohd Suki, N. (2015). Does Religion Influence Consumers' Green Food Consumption? Some Insights from Malaysia. Journal of Consumer Marketing, 32(7), 551-563. https://doi.org/10.1108/JCM-02-2014-0877

Mukhtar, A., \& Mohsin Butt, M. (2012). Intention to choose Halal Products: the Role of Religiosity. Journal of Islamic Marketing, 3(2), 108-120. https://doi. org/10.1108/17590831211232519

Nana, A. (2013). Saudi Ulema say that $90 \%$ of Halal Meat is Haram. Retrieved from http://www.radioislam.org.za/a/index.php/podcasts/

Neiburg, O. (2013). Catering to the Middle East: Halal Certification and AlcoholFree Labeling with Mondelez. Retrieved from https://www.confectionerynews. com/Article/2013/01/28/Halal-chocolate-and-alcohol-free-confectionery-withMondelez

O'Cass, A. (2000). An Assessment of Consumer Product, Purchase Decision, Advertising and Cosumption Involvement in Fashion Clothing. Journal of Economic Psychology, 21(5), 545-576.

Omar, E. N., Jaafar, H. S., \& Osman, R. (2011). Procedia Social and Behavioral Sciences Assessing Halalan-Toyyiban Food Supply Chain in the Poultry Industry. Procedia -Social and Behavioral Sciences Emi Normalina Omar/ Procedia -Social and Behavioral Sciences, 00(00), 0-0. Retrieved from www.elsevier.com/ locate/procedia

Othman, C., \& Rahman, M. S. (2014). Investigation of the Relationship of Brand Personality, Subjective Norm and Perceived Control on Consumers' Purchase Intention of Organic Fast Food. Modern Applied Science, 8(3), 92-106. https:// doi.org/10.5539/mas.v8n3p92

Power, C. (2008). Halal Goes Global.

Reuters, T. (2015). State of the Global Islamic Economy. Dubai the Capital of Islamic Economy, 1-287. https://doi.org/10.1017/CBO9781107415324.004

Riaz, M. N., \& Chaudry, M. M. (2004). Halal Food Production. Boca Raton, FL: CRC Press.

Sabri, M. (2006). IslamOnline.net. Retrieved from http://islamonline.net/English/ News/2006-01/19/article04.shtml

Said, M., \& Hassan, F. (2014). The Antecedents of Halal Consumption Congruence (HaCC) of Malaysia's Halal Food Products: A Conceptual Approach. Australian Journal of Basic and Applied Sciences, 8(S3), 140-148. Retrieved from http://www. ajbasweb.com/old/ajbas/2014/Special 3/140-148-special14.pdf

Salehudin, I., \& Luthfi, B. A. (2011a). Marketing Impact of Halal Labeling toward Indonesian Consumer's Behavioral Intentions. Asean Marketing Journal, 3(1) (June), 35-44. 
Salehudin, I., \& Luthfi, B. A. (2011b). Marketing Impact of Halal Labeling toward Indonesian Muslim Consumer's Behavioral Intention. Asean Marketing Journal, (June).

Saunders, M., Lewis, P., \& Thornhill, A. (2008). Research Methods for Business Students. Research methods for business students. https://doi.org/10.1007/s13398014-0173-7.2

Schumacker, R. E., \& Lomax, R. G. (2010). A Beginner's Guide to Structural Equation Modeling. https://doi.org/10.1002/9781118133880.hop202023

Sekaran, U., \& Boogie, R. (2010). Research Methods For Business A Skill-Building Approach (5th Editio). Chichester, West Sussex, United Kingdom: John Wiley \& Sons Ltd.

Shah Alam, S., \& Mohamed Sayuti, N. (2011). Applying the Theory of Planned Behavior (TPB) in Halal Food Purchasing. International Journal of Commerce and Management, 21(1), 8-20. https://doi.org/10.1108/10569211111111676

Tarkiainen, A., \& Sundqvist, S. (2005). Subjective Norms, Attitudes and Intentions of Finish Consumers in Buying Organic Food. British Food Journal, 107(11), 808-822. https://doi.org/10.1108/00070700510629760

Tieman, M. (2015). Halal Clusters. Journal of Islamic Marketing, 6, 2-21. https://doi. org/10.1108/JIMA-05-2014-0034

Tifaoui, S. (2011). Muslim Immigrants' Attitudes and Perceptions towards Halal Meat in Spain.

Vermeir, I., \& Verbeke, W. (2008). Sustainable Food Consumption among Young Adults in Belgium: Theory of Planned Behavior and the Role of Confidence and Values. Ecological Economics, 64(3), 542-553.

Widodo, T. (2013). The Influence of Muslim Consumers Perception Toward Halal Food Product on Attitude and Purchase Intention at Retail Stores. Jurnal Ekonomi Dan Bisnis, (1), 1-30.

Wilson, J. A. J., \& Liu, J. (2010). Shaping the Halal into a Brand? Journal of Islamic Marketing, 1(2), 107-123. https://doi.org/10.1108/17590831011055851

Wilson, J. A. J., Liu, J., Lada, S., Tanakinjal, G. H., \& Amin, H. (2010). Shaping the Halal into a Brand? Journal of Islamic Marketing Journal of Islamic Marketing Iss International Journal of Islamic and Middle Eastern Finance and Management Iss Journal of Islamic Marketing, 1(2), 107-123. Retrieved from http://dx.doi. org/10.1108/17590831011055851

Yayımlandığı Resmi Gazete. (2009). Türk Gıda Kodeksi Yönetmeliği Et Ürünleri Tebliği. Yayımlandı̆̆ı Resmi Gazete.

Yıldırım, B. (2011). Helal gida. Retrieved from http://www.gidagundemi.com/ helal-gida-makale, 17.htm 